\title{
A regional tectonic event of Katian (Late Ordovician) age across three major blocks of China
}

\author{
CHEN Xu ${ }^{1,2^{*}}$, BERGSTRÖM Stig $\mathrm{M}^{3}$, ZHANG YuanDong ${ }^{1,2} \&$ WANG ZhiHao ${ }^{1}$ \\ ${ }^{1}$ Nanjing Institute of Geology and Palaeontology, Chinese Academy of Sciences, Nanjing 210008, China; \\ ${ }^{2}$ Key Laboratory of Economic Stratigraphy and Palaeogeography, Chinese Academy of Sciences, Nanjing 210008, China; \\ ${ }^{3}$ School of Earth Sciences, Division of Geological History, The Ohio State University, Columbus, Ohio 43210, USA
}

Received April 16, 2013; accepted May 31, 2013; published online July 24, 2013

\begin{abstract}
The present paper deals with a tectonic event of Late Ordovician age affecting three blocks of China, i.e. South China, North China and Tarim. In the North China and the Tarim platforms, as well as their marginal belts, there was a regional uplift during the early Katian Stage of the Ordovician. The uplift was indicated by the unconformities between the Ordovician successions and overlying late Paleozoic strata. New biostratigraphic studies of conodonts and graptolites from many sections at Longxian and Yaoxian, North China shows that the youngest Ordovician strata are of the early Katian age corresponding to graptolite Diplacanthograptus spiniferus Biozone. The same level has been recognized to represent the uppermost Ordovician in the platform area of Tarim, whereas in the marginal belt the top boundary of the Ordovician is slightly younger, corresponding to the graptolite Dicellograptus complanatus Biozone. Thus, the regional uplift in North China and Tarim is shown by the disconformity between the early Katian strata and Late Paleozoic strata, the onset coinciding with that of the Kwangsian Orogeny in South China. The designation Kwangsian Orogeny later fell into disuse and was replaced by the term Caledonian Orogeny. However, in terms of geographic location, tectonic nature, and the timing of activity, the Caledonian Orogeny differs significantly from the orogenic event in South China, and the continued use of this term in South China is inappropriate and misleading.
\end{abstract}

North China, Tarim, Ordovician, regional tectonic event, Kwangsian Orogeny

Citation: Chen X, Bergström S M, Zhang Y D, et al. A regional tectonic event of Katian (Late Ordovician) age across three major blocks of China. Chin Sci Bull, 2013, 58: 4292-4299, doi: 10.1007/s11434-013-5990-0

A major angular unconformity is present between the Lower Devonian and the underlying older rocks in southeast China, which represents a major tectonic event. The tectonic event was first recognized by a Chinese senior geologist, the late professor Ting in 1929 [1], who named it with an appropriate term, the Kwangsian Orogenic Movement. This term was not, however, commonly adopted by Chinese geologists and later the tectonic movement was referred to by a more popular term, the Caledonian Movement, as suggested by the late professor Huang [2]. In recent years, we conducted an intensive study of aspects of the Kwangsian Orogeny [3-5] and were able to constrain the timing of its onset and stages in South China [6]. On the basis of this

*Corresponding author (email: xuchen@ nigpas.ac.cn) study, we further recognized a contemporary tectonic event in North China and Tarim, though in different magnitudes and time durations. Therefore, we extend our study into these presumably related tectonic movements in North China and Tarim, based mainly on stratigraphic and palaeontological evidence.

The Kwangsian Orogeny might include two stages: (1) the uplift stage, which started from the Diplacanthograptus caudatus-Diplacanthograptus spiniferus Biozone interval and extended into early Silurian in a stepwise manner, and (2) the final orogenic paroxysm as indicated by the angular unconformities to the east of Xuefeng Mts. and the disconformities on Yangtze Platform. Recently, we published another paper dealing with the onset of the Kwangsian Orogeny based on biofacies and lithofacies across South China 
[7], in which we recognized that the interval of the origination of Kwangsian Orogeny also coincided with tectonic uplift events in the neighboring blocks, i.e. North China and Tarim. Their coincidence in three separate blocks of China seems to represent a major tectonic event during the Early Paleozoic in China. In geological scale, tectonic events that happened within the same interval of 2-3 million years would be reasonably treated as simultaneous. As a consequence of this uplift, an erosion surface was formed on the top of the Ordovician in North China and Tarim, which may have facilitated the later movement of oil and gas.

In order to date this uplift, the present study reviews the published conodont records from the top part of the Ordovician carbonate sequences at different localities on the platforms and marginal belts of North China and Tarim. Graptolites from near the top of the Ordovician successions in these regions are also studied herein. Dating of the unconformities of late Ordovician in both North China and Tarim is critical as they indicate the initiation and end time of the uplift. However, the erosion surfaces in the top part of the Ordovician in these two blocks do not seem to be synchronous, which indicates the presumably asynchronous end of the erosion in different parts of the platform and marginal belt, and therefore can be used to constrain approximately the timing of the uplift. We expect that the present integrated study of the uplift events across the three major blocks of China may significantly improve our understanding of the geological history of the China.

\section{Top surface of the Ordovician in North China}

The Ordovician rocks on the platform of North China are dominated by shallow-water limestone and dolomitic limestone containing abundant shelly fossil faunas and conodonts. Graptolite-bearing shale occurs only in the west marginal belt to the platform [8]. Conodonts are definitely the most useful fossil group for dating the Ordovician rocks on the platform, whereas both graptolites and conodonts are biostratigraphically diagnostic for the strata of the marginal belt.

Our review of the Darriwilian-Sandbian conodont biostratigraphy of the platform region of North China aims to clarify the youngest age of the Ordovician carbonate succession below the unconformities with overlying middleupper Paleozoic strata. Chinese authors, especially An et al. [9], collected hundreds of samples from many key sections and illustrated quite a few conodont taxa based on their collections. They identified a number of new taxa, and established a conodont zonation, which has been adopted for the entire region. However, many of the key conodont taxa are more or less endemic and are not recorded elsewhere, for instance, in Baltoscandia and North America. This makes it somewhat difficult to precisely correlate most of the Darriwilian and Sandbian conodont zones in the region to those of Baltoscandia and North America. Nevertheless, the occurrence of a few diagnostic species in North China, such as some representative species of Lenodus and Eoplacognathus, provides important ties to the Baltoscandian successions. The Middle-Late Ordovician faunas from the platform region of North China are by and large more similar to the coeval faunas of the North American Midcontinent than to the Baltoscandian ones, as evidenced by the occurrence of Belodina, Plectodina, Microcoelodus and Erismodus in North China. On the other hand, the conodont faunas exhibit their own provincial characters, as indicated by the common occurrences of Baduodus, Tasmanognathus, Yaoxianognathus and Aurilobus, etc.

An et al. [9] proposed the first conodont-based correlation chart for the platform region of the North China platform, which summarized the youngest age of the Ordovician successions. In the correlation chart, the tops of the Ordovician in North China (NC) are represented by the Upper Machiakou Formation in Benxi and Tangshan (Northern NC) and Huinan (Northeastern NC), by the Fengfeng Formation (split by some specialists into Gezhuang and Badou formations in ascending order) in Fengfeng, Xintai and Xuzhou (Central and Eastern NC). However, on the west marginal belt at Longxian, the topmost part of the Ordovician is represented by Beiguoshan Formation, whose age is slightly younger than in the platform region (Figures 1 and 2). An et al. [9] recognized a Belodina compressaMicrocoelodus symmetricus Biozone in the upper member (Badou Member) of the Fengfeng Formation at Sishui, Mengyin, Boshan, Penglai (Shandong Province), Handan (Hebei Province) and Tongchuan (Shaanxi Province). A similar conodont association was found in a few drill cores in Shandong Province, but no conodonts were recorded from the topmost 50 meters of the member, which suggested that the top could be slightly younger. The identifications are reasonable based on our currently somewhat incomplete understanding of the taxonomy of these faunas. The few illustrated conodont species from the type section of the Fengfeng Formation at Handan, Hubei Province, were not provided with sampled levels, which significantly limits their biostratigraphic utility.

The youngest conodont taxa from the Badou Member of the Fengfeng Formation at Boshan and Mengyin, Shandong Province, as shown by An et al. [9, Figure 8], include Badoudus badouensis, Panderodus gracilis, Belodina compressa, Microcoelodus asymmetricus (including M. symmetricus as a multielement species), Erimodus typus and Tasmanognathus sishuiensis. This conodont association is comparable to that of the Plectodina aculeata-Erismodus quadridactylus Biozone as represented in the Joachim-Plattin formations in the Upper Mississippi Valley of North America [10]. In terms of global standard stages, this interval is of late Sandbian age and corresponds largely to the graptolite Climacograptus bicornis Biozone. In the southern part of North China, Pei and Cai [11] investigated the conodonts 
of the Fengfeng Formation in Boai, Hebi, Anyang and Tongye counties, Henan Province. In this study a few species from the Fengfeng Formation in Queshan, Boai, Hebi and Anyang (Henan Province) were illustrated [11] (Figure 1). They identified a conodont zone, the Tasmanognathus careyi Biozone, in the lower member of the Fengfeng Formation in the area, which is just above the Aurilobodus serratus Biozone in the topmost Machiakou Formation. They correlated the $T$. careyi Biozone to its equivalent in Tasmania, Australia. However, in a recent revision of $T$. careyi based on the type material and additional collections from the latest Sandbian to earliest Katian Benjamin Limestone of Tasmania by Zhen et al. [12], most of the identifications of this species from North China were questioned. Hence, the validity of Pei and Cai's [11] biozone recognition is in doubt. At any rate, because this zone is in the lower Fengfeng Formation, it has no direct bearing on the dating of the topmost part of the Ordovician succession in this region. Pei and Cai [11, Figures 2-8] listed Microcoelodus symmetricus, Belodina compressa, B. confluens (=B. compressa), Erismodus typus and Microcoelodus sp. from the lower-middle part of the Upper Member of the Fengfeng Formation at Anyang, Henan, which suggested a late Sandbian age, and based on which $M$. symmetricus Biozone was recognized and correlated to the B. compressa-M. symmetricus Biozone in Shandong and Hebei Provinces. As evidenced by the absence of the upper member of the Fengfeng Formation at Boai, Henan Province [11], it seems likely that at some localities portions of the Fengfeng Formation was eroded after the emergence (Figure 1).

Wang and Luo [13] identified a conodont fauna from the Beiguoshan and Taoqupo formations in Longxian and Yaoxian on the western margin of North China (Figure 1). One year later, An et al. [14] also illustrated a few cono- donts from the Taoqupo Formation at the same locality in Yaoxian, Shaanxi Province. The Taoqupo Formation represents the topmost part of the Ordovician in the Shaanxi Province, and contains a conodont association of Belodina compressa, Yaoxianognathus yaoxianensis, Dapsilodus mutatus, and Phragmodus undatus, which suggests an early Katian age, and hence slightly younger than Fengfeng Formation.

The Beiguoshan Formation represents the topmost part of the Ordovician in the Gansu Province. The conodont fauna of the formation, which has been described by Wang and Luo [13] and An and Zheng [15], includes, among others, Belodina confluens, Protopanderodus insculptus, and Scabbardella similaris, suggesting an early Katian or younger age. The formation is largely equivalent to the Taoqupo Formation in the neighboring Shaanxi Province [8].

In brief, the available conodont evidence indicates that the top of the Ordovician succession in most parts of the platform region of North China is of Sandbian age, whereas that on the west and south marginal belts of the platform is of early Katian age. Hence, the erosion surface at the top of the Ordovician in North China is of an age prior to late Katian.

Graptolites are very rare in the platform region of North China. Only one species, Didymograptus cf. pandus Bulman, is described from the Upper Machiakou Formation near Huaibei City, N. Anhui [16]. The age of the species, commonly middle Darriwilian, agrees with that of the conodont fauna in the southern part of North China. Fortunately, along the marginal belt of the platform, biostratigraphically diagnostic graptolite faunas are present. In Longxian, Shaanxi Province, four graptolite species, the Diplacanthograptus spiniferus (Ruedemann), D. lanceolatus Vandenberg, Dicellograptus flexuosus Lapworth and

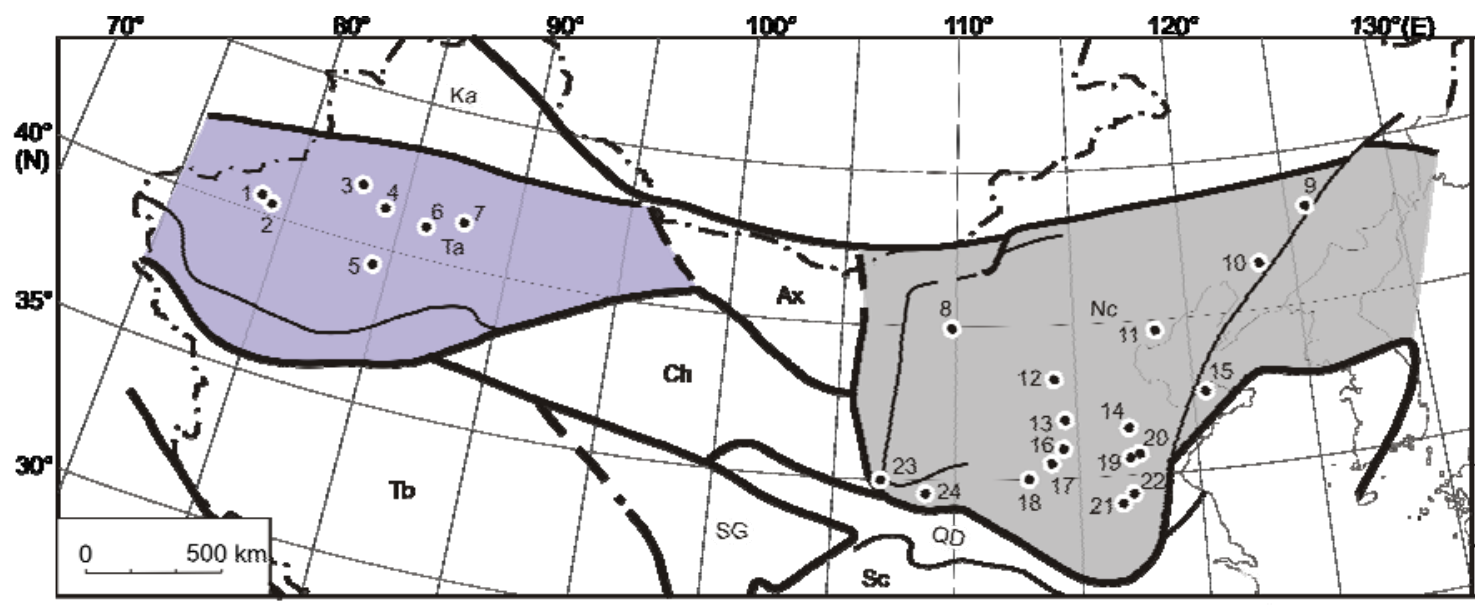

Figure 1 Orientation map to show the localities examined in North China and Tarim. Ka, eastern parts of Kazakhstan Block; Ta, Tarim; Ax, Alashan Block; Nc, North China; Ch, Chaidam Block; Tb, Tibet Bltock; SG, Songpan-Garze (Ganzi) Block; QD, Qinling-Dabie orogen; Sc, South China; 1, Wushi, Xinjiang; 2, Kalpin, Xinjiang; 3, Kuqa, Xinjiang; 4, South Luntai, Xinjiang; 5, Central Tarim, Xinjiang; 6, Southern Korla, Xinjiang; 7, Kuruktag, Xinjiang; 8, Ordos, Inner Mongolia; 9, Huinan, Jilin; 10, Benxi, Liaoning; 11, Tangshan, Hebei; 12, Tongye, Henan; 13, Xintai, Hebei; 14, Boshan, Henan; 15, Penglai, Shandong; 16, Anyang, Henan; 17, Hebi, Henan; 18, Boai, Henan; 19, Sishui, Shandong; 20, Mengyin, Shandong; 21, Huaibei, Anhui; 22, Xuzhou, Jiangsu; 23, Longxian, Shaanxi; 24, Yaoxian-Jingyang, Shaanxi. 
Orthograptus whitfieldi (Hall) occur in the top part of Longmendong Formation, which is overlain by the Beiguoshan Formation. The first occurrence of $D$. spiniferus may indicate the base of the eponymous biozone. The others might range down into the underlying Diplacanthograptus caudatus Biozone. The Beiguoshan Formation bears a shelly fauna, including trilobites, nautiloids and brachiopods, and conodonts as well. The shelly fauna indicates a late Caradocian age [17]. Based on the conodonts, one of the present authors (WZH) recognized the Yaoxianognathus yaoxianensis-Belodina confluens Biozone from the formation [8], which is of early Katian age.

In Yaoxian and Jingyang counties on the southwest marginal belt of North China, a graptolite fauna from the Taoqupo Formation, which represents the local top of the Ordovician, was described by Lin [18]. An unconformity separates the Taoqupo Formation and its overlying rocks, the Benxi Formation of the Pennsylvanian (Carboniferous). A reinvestigation of this graptolite fauna during the present study by Chen $\mathrm{Xu}$ resulted in revised identifications of the Taoqupo Formation graptolites. After the revision, the fauna contains Diplacanthograptus lanceolatus Vandenberg, Orthograptus quadrimucronatus (Hall), O. calcaratus acanthocladus Lin, O. longithecalis $\mathrm{Mu}$ and Zhang, Rectograptus amplexicaulis (Hall), R. intermedius (Elles and Wood), $R$. pauperatus (Elles and Wood), Amplexograptus maxwelli Decker, A. praetypicalis Riva, A. praetypicalis subsp. nov., Anticostia sp. nov., and Normalograptus cf. daviesi (Williams). Camera-lucida drawings of these specimens are included in the present paper. Species of orthograptids in the fauna have a relatively long range through the early Katian. However, the occurrences of A. praetypicalis, A. maxwelli and $D$. lanceolatus may indicate an interval of the $D$. spi- niferus Biozone that is coeval with the same biozone of the Yingan Formation at Dawangou, Kalpin in western Tarim [19]. The other forms in this fauna, largely endemic, possess less correlative value.

As mentioned above, the age of the graptolite fauna or species on the platform region and west marginal belt of North China, is in agreement with that shown by the conodonts on the platform and suggests that the topmost part of the Ordovician succession is of an age corresponding to $D$. spiniferus Biozone or older. Upper Katian and Hirnantian in this large region are completely missing (Figure 2).

\section{Top surface of the Ordovician in Tarim}

Ordovician rocks in the Tarim basin are dominated by carbonates containing conodonts. The conodonts were obtained mainly from drill cores of oil companies. Zhao Zhixing, a senior geologist of Petro China, with his colleagues published the conodonts from the Ordovician outcrops as well as drill core samples in the Tarim basin [20]. A few graptolite specimens were obtained from the drill cores in central Tarim [21] and many more specimens have been collected from the marginal belts, i.e. the Kalpin area in the west and Kuruktag area in the east [22]. Most of our knowledge about conodonts from the uppermost part of the Ordovician in the subsurface of the Tarim Basin is based on the extensive monograph by Zhao et al. [20] on collections from drill cores. Their information indicates that the stratigraphically uppermost conodonts in most drill cores are of pre-Katian age. However, a record of Aphelognathus pyramidalis from a drill core at South Luntai (\#Ln 46) [20, pl. 48, Figures 10, $11,17]$ suggests a Katian age, indicating the highest top

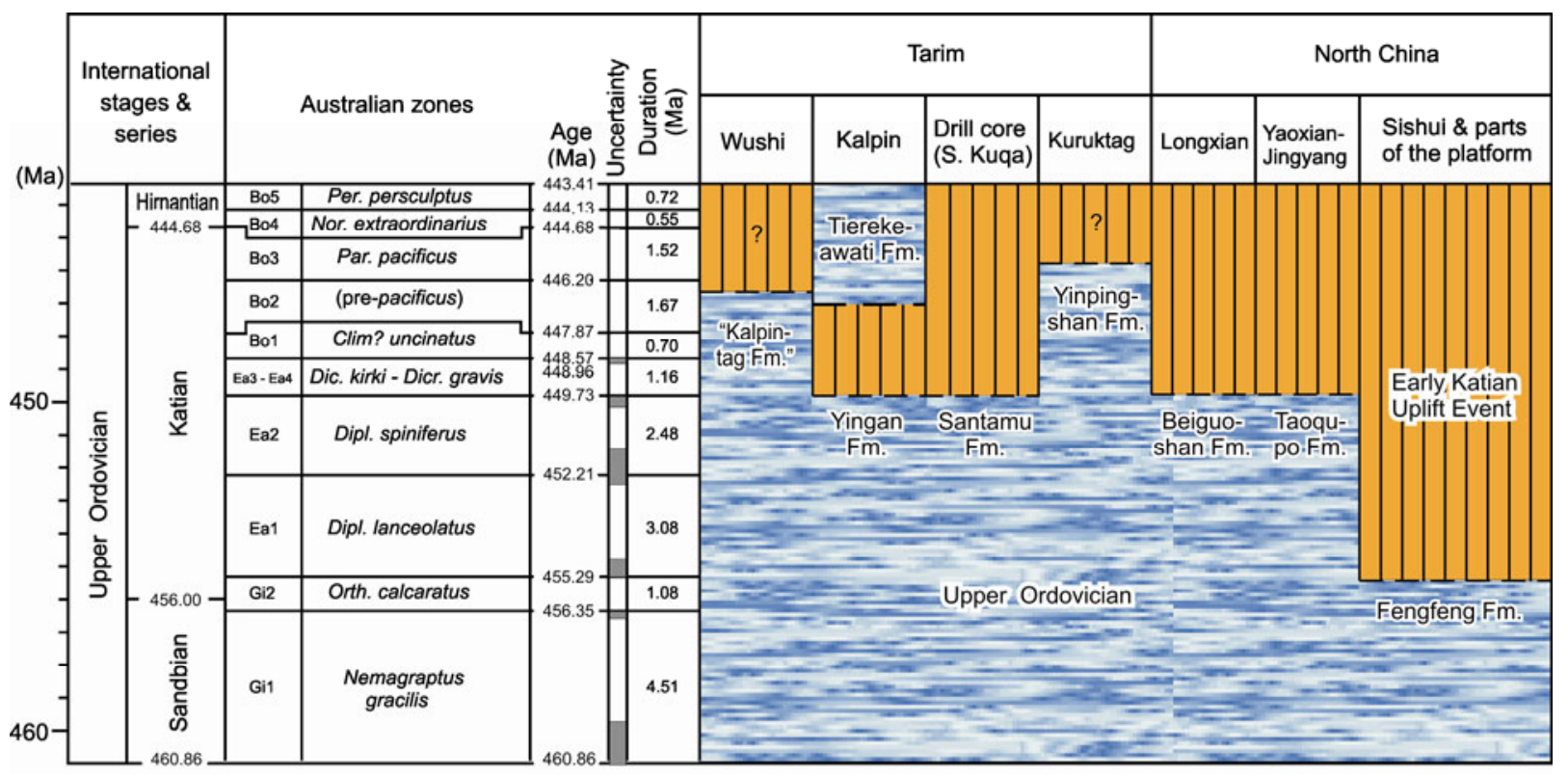

Figure 2 A correlation of the topmost Ordovician in North China and Tarim. 
surface of the Ordovician within the Tarim basin.

Additional useful information about conodonts from a drill core south of Luntai in the Taklimakan desert is provided by Wang and Qi [23]. They recognized the Aphelognathus pyramidalis Biozone as the youngest conodont zone of the Ordovician succession. This biozone, also recognized in the Kuruktag area in eastern Tarim, is characterized by the species association of, among others, A. pyramidalis, Belodina confluens, Pseudobelodina dispansa and Taoqupognathus blandus, which indicates an early Katian age. Upper Katian and Hirnantian are missing everywhere as indicated by all available data, and it seems likely that early Katian deposits are very poorly represented in the subsurface of Tarim Basin.

Graptolites are very rare in the Tarim basin. Chen et al. [22] recorded from a drill-core near south Kuqa (Figure 1) the graptolites Amplexograptus praetypicalis Riva, Rectograptus amplexicaulis (Hall), and Hustedograptus cf. teretiusculus (Hisinger), a species association suggesting an age no younger than the Diplacanthograptus spiniferus Biozone. So far, this is the only known location yielding graptolites within Tarim Basin and the graptolites-bearing level may represent the local top of the Ordovician. The top surface of the Ordovician within Tarim basin might be of the same age (i.e. the D. spiniferus Biozone) as that in the Dawangou section, which is situated in the upper slope belt of the western Tarim marginal belt. Thus, the data available indicate the occurrence of an uplift event in both Tarim basin and the western upper slope belt, which caused a contemporary emergence of the regions. However, a Dicellograptus complanatus Biozone fauna was recorded from Wushi County to the north of Kalpin, where belongs to the lower slope facies of the western marginal belt [22]. At this locality, D. complanatus Lapworth is associated with Anticostia macgregorae Stewart and Mitchell and the fauna represents the $D$. complanatus Biozone. On the east side of Tarim, a similar D. complanatus fauna occurs in South Korla as well as in the Kuruktag region.

In terms of conodont biostratigraphy in the west marginal belt of Tarim, the youngest Ordovician strata (i.e. the Yingan Formation of early Katian age, or the Tierekeawati Formation of possibly late Katian age) in the well-known Dawangou succession yields no conodonts. At Dawangou, the youngest recovered Ordovician conodonts are from the Kanling Formation (latest Sandbian) and they represent the Baltoniodus alobatus Subbiozone of the Amorphognathus tvaerensis Biozone [24]. However, at Yakrik, Wushi County, ca. $70 \mathrm{~km}$ west of Aksu, a significantly younger conodont fauna has recently been recorded [25]. The biostratigraphically youngest conodont species association in this thick succession includes, among others, Aphelognathus pyramidalis, A. politus, Phragmodus? tunguskaensis, Yaoxianognathus yaoxianensis, and Belodina confluens, a species association indicating an early to middle Katian age, which might be about the $D$. spiniferus Biozone interval.
The conodonts-bearing interval is succeeded by shaly strata containing graptolites of the Dicellograptus complanatus Biozone. The strata presumably present between the conodont and the graptolite beds have not yet been confirmed at Yakrik. The current authors recognized that the top surface of the Ordovician in Wushi, where seems to be lower slope facies, is comparable in age with that of the similar facies at South Korla and Kuruktag, and may represent stratigraphic level higher than in Tarim Basin (Figure 2).

Recently, Tang Peng and others (per. comm.) successfully identified a chitinozoan association of Armoricochitina yinganensis Biozone from the Tierekeawati Formation (the basal part of the former Kalpintag Formation), which is closely correlated with the chitinozoan association of late Katian from the Xiazhen and Hongjiawu formations in the Yushan of eastern Jiangxi Province, South China. The discovery of this late Katian chitinozoans association from the Tierekeawati Formation confirms the presence of strata corresponding to graptolite Dicellograptus complanatus Biozone in the Kalpin area, and indicates the development of a minor hiatus between the Yingan Formation and the overlying Tierekeawati Formation. In the Yakrik area to the northwest of Kalpin, the presence of strata corresponding to Dicellograptus complanatus Biozone has been confirmed [22], but the presence or absence of younger Ordovician strata has to be confirmed by further study. In the Kuruktag area of eastern Tarim, late Ordovician marine strata corresponding to the Dicellograptus complanatus and Dicellograptus ornatus biozones have been confirmed, whereas younger strata might be missing there. So, the overall uplift of late Ordovician in the eastern and western Tarim is slightly younger than that in the central platform area.

\section{Equivalence of the Early Katian Uplift in Southeastern China, North China, and Tarim}

It is widely known that continental emergence may be caused by two factors, namely eustatic sea level lowering or regional cratonic uplift, or more rarely, a combination of these processes. An example of the first process is the global Hirnantian regression caused by the formation of geographically very extensive glaciers in the Gondwana region. The magnitude of the Hirnantian eustatic regression ranges, as commonly estimated, from tens of meters to over 100 meters. This sea level fall resulted in the emergence of the former shallow-water regions and simultaneously a change from sediments deposition into erosion. An example of regional cratonic uplift without clear evidence of a major eustatic sea level lowering is the late Early-early Middle Ordovician succession in the Midcontinent of North America, where a several million years long period of regional nondeposition resulted in the formation of the widespread and very prominent Sauk-Tippecanoe unconformity [26].

The broadly coeval interruptions of deposition in south- 
east China, North China Platform, and Tarim as described above were initiated in the early Katian of the Late Ordovician Series. Typically, the platform regions of shallow-water depositional environments became emergent first while in the deeper-water regions along the platform margins the depositional process continued until their eventual, later emergence. In most regions dealt with herein, Hirnantian and Silurian strata are absent and deposition was not resumed until Devonian-Carboniferous time.

Indeed, there are various significant problems with little agreement in the published Ordovician eustatic sea level curves [27-31]. Nevertheless, a review of Sandbian-Katian sea level curves from North America [30] and Baltoscandia $[29,31]$ suggests the absence of a major early Katian sea level lowering that could be interpreted as coeval with, and hence caused, the emergence of the Chinese regions dealt with herein. Accordingly, we feel that this emergence was not directly associated with a eustatic sea level lowering but represents a true continental tectonic uplift. The absence of ophiolites and other evidence of plate collision suggest that at least initially, the uplift was not related to any collisions.

As shown in Figure 3, the Chinese regions dealt with herein were located rather closely together and far from the Caledonian area in northwestern Europe and the corresponding region in the Appalachians of eastern North America. As noted above, this makes it highly unlikely that the tectonic event referred to as the Kwangsian Orogeny herein has anything at all to do with the Caledonian Orogeny. On the other hand, the relatively close geographical association of the North China Platform and Tarim supports the idea that the uplifts of these regions may have been genetically related. However, whether this regional uplift has any relationship to the broadly coeval Kwangsian Orogeny in southeastern China requires further study, although these events happened within the same time interval. In these matters, particular guidance from tectonic specialists is indispensable.

\section{Conclusions}

Both the graptolite and conodont evidence supports the conclusion that the uplift in most platform regions of North China is of late Sandbian to early Katian age. The west marginal belts of North China emerged during the early Katian, which coincides with the graptolite record of Diplacanthograptus spiniferus Biozone. The occurrence of the Katian conodont species Aphelognathus pyramidalis within the Tarim Basin provides a date of the youngest Ordovician strata, which coincides roughly with or is slightly younger than the occurrence of the graptolite Amplexograptus praetypicalis, etc. in a drill core in Central Tarim. Thus, we assume that the Tarim Platform once emerged in the early Katian, but its western and eastern marginal belts might have been uplifted later during the late Katian Dicellograptus complanatus Biozone interval. For readers' reference, we illustrate herein some figures of the discussed graptolites and conodonts that serve as major evidence to support our conclusions (Figure 4). The broadly contemporary uplift of North China and most of Tarim during late Sandbian-early

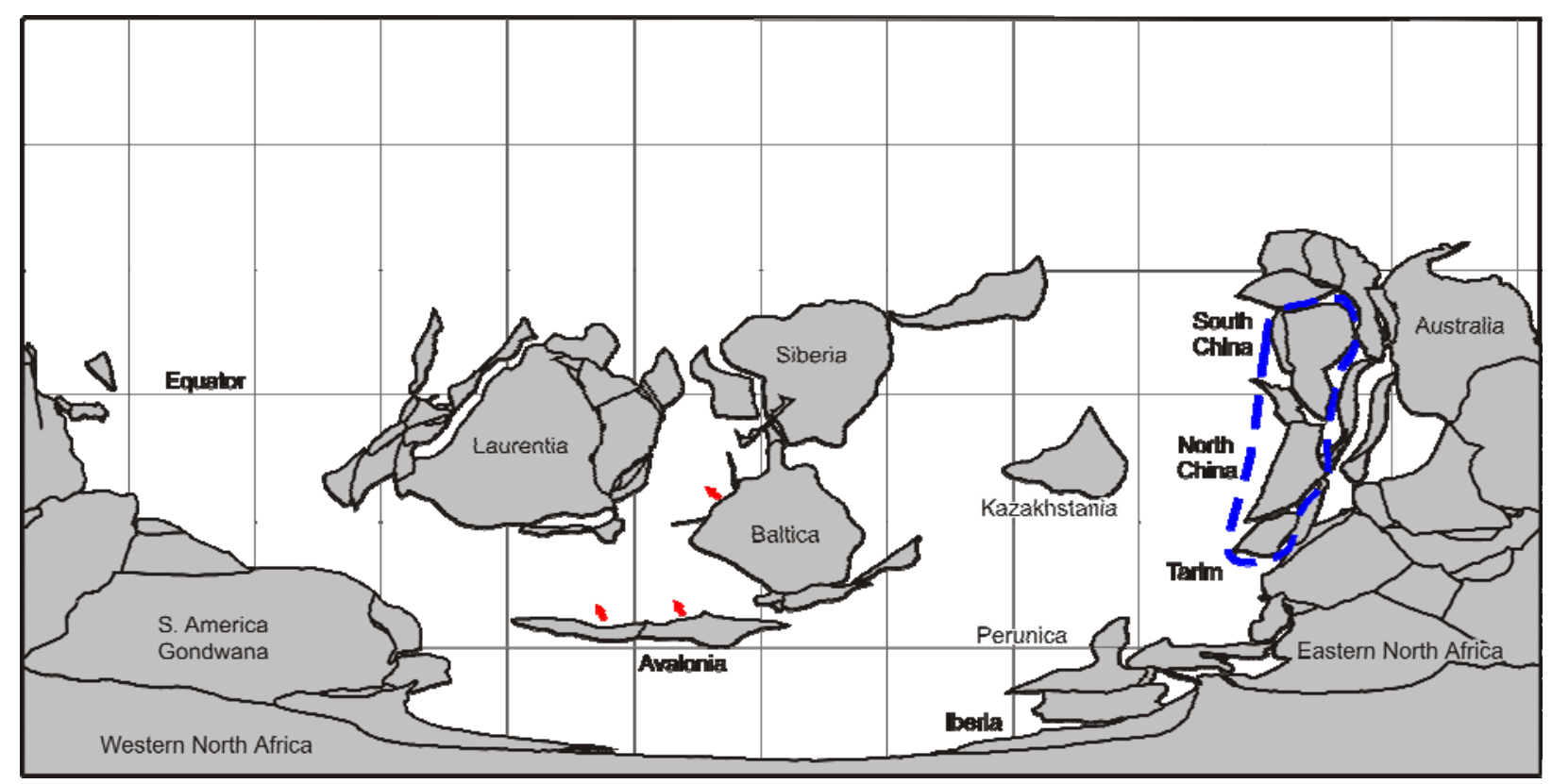

Figure 3 Map showing the reconstructed global palaeogeography in Sandbian (late Ordovician). Note the differences between the northeastern Peri-Gondwanan region, where South China, North China and Tarim were located (blue dash line), and the plates around the Iapetus Ocean (i.e. Laurentia, Siberia, Baltica and Avalonia. Red arrows indicate rifting directions). The base map is after Goldman et al. [32], PaleoGIS 4.0 for ArcGIS: The Rothwell Group, L.P. (www.paleogis.com). 

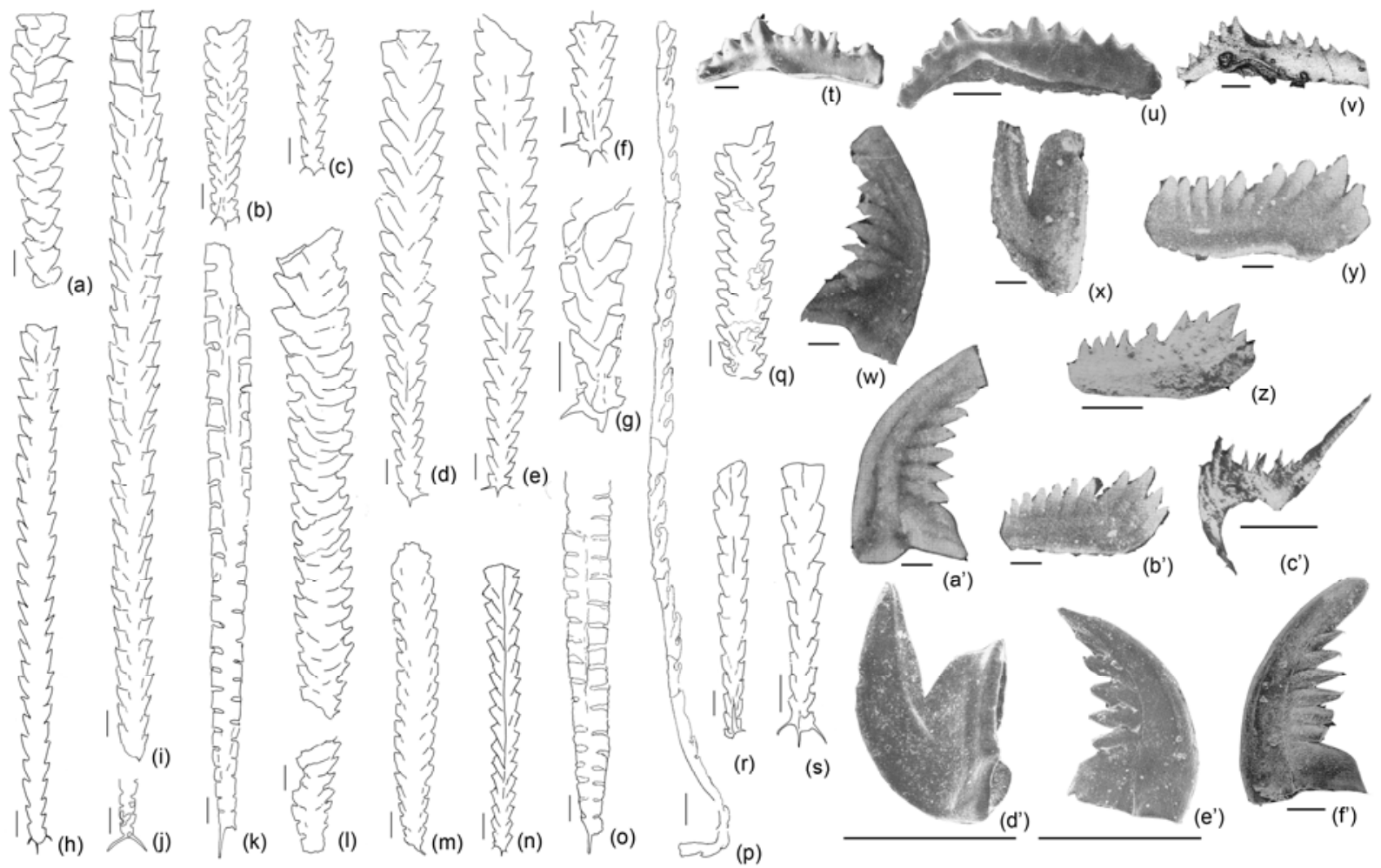

Figure 4 Illustration of the Katian graptolite and conodont taxa discussed in the text. Graptolites (from the Taoqupo Formation at Taoqupo, Yaoxian, Shaanxi Province, except for those specified): (a) Amplexograptus maxwelli Decker, 1935 (=Orthograptus nodulus Lin sensu Lin, 1996 [18]), NIGP118698. (b), (g), (q) Amplexograptus praetypicalis Riva, 1987. (b) (=Orthograptus calcaratus vulgatus Lapworth sensu Lin, 1996 [18]) NIGP118679. (g) (=Diplograptus vespertinus Ruedemann sensu Lin, 1996 [18]) NIGP118639. (q) NIGP152520, central Tarim, Diplacanthograptus spiniferus Biozone. (c), (e) Rectograptus intermedius (Elles and Wood, 1907). (c) (=O. calcaratus basilicus Lapworth sensu Lin, 1996 [18]), NIGP118664. (e) (=Diplograptus vespertinus Ruedemann sensu Lin, 1996 [18]), NIGP 118643. (d) Rectograptus amplexicaulis (Hall, 1847) (=Diplograptus vespertinus Ruedemann sensu Lin, 1996 [18]), NIGP118638. (f) Rectograptus pauperatus (Elles \& Wood, 1907) (=O. truncatus pauperatus Elles and Wood sensu Lin, 1996 [18]), NIGP118689. (h) Orthograptus calcaratus acanthocladus Lin 1996, NIGP118660 (Holotype). (i) Orthograptus quadrimucronatus (Hall, 1865) (=Orthograptus calcaratus gracillinuis Lin sensu Lin, 1996 [18]). C. (D.) spiniferus Biozone. The characteristics of the specimen agree well with those of the same species from Quebec, Canada [33]. NIGP118671. (j) Diplacanthograptus spiniferus (Ruedemann, 1912). Yingan Formation at Dawangou, Kalpin, Xinjiang, NIGP127031 (Nj 571). (k), (o) Diplacanthograptus lanceolatus (VandenBerg, 1990). (k) (=Climacograptus pseudoparvus He sensu Lin, 1996 [18]), NIGP118654. (o) (=Climacograptus pseudoparvus He sensu Lin, 1996 [18]), NIGP118654. (1) Amplexograptus perexcavatus (Lapworth, 1876) (=Orthograptus nodulus Lin sensu Lin, 1996 [18]), NIGP118696. (m) Normalograptus cf. daviesi (Williams, 1982) (=Glyptograptus daviesi Williams sensu Lin, 1996 [18]), NIGP118648. (n) Rectograptus longithecalis Mu et Zhang, 1982, NIGP118684. (p) Dicellograptus cf. complanatus Lapworth, NIGP152534 (AFT-X148a), Yingpinshan Formation at Mt. Queerquek, Kuruktag, Xinjiang. (r) Anticostia macgregove Stewart \& Mitchell, 1997, NIGP152524, Yakrik, Wushi, Xinjiang, Dicellograptus complanatus Biozone (Wyk-HB-26-10). (s) Anticostia sp. nov. (=Orthograptus longithecalis Mu et Zhang sensu Lin, 1996 [18]), NIGP118689. Conodonts: (t), (u), (v) Aphelognathus pyramidalis (Branson, Mehl et Branson, 1951). (t) Lateral view of Pb element, Ln 46 Well, Tarim of Xinjiang, Upper Ordovician Lianglitag Formation, Ln46/132427; (u) Lateral view of Pb element, Wushi of Tarim of Xinjiang, Upper Ordovician Lianglitag Formation, G99-2068/2000-2-27; (v) Lateral view of Pb element, Wushi, Tarim of Xinjiang, Upper Ordovician Kalpintag Formation, WYK-Y-14-04. (w), (x), (a') Belodina compressa (Branson et Mehl, 1933). (w), (a') Lateral views of S1 element, Taoqupo of Longxian, Shaanxi, Upper Ordovician Beiguoshan Formation, Leb4-1/65336; (x) Lateral view of M element, Yaoxian of Shaanxi, Upper Ordovician Taoqupo Formation, Yt40-1/65252. (y), (z), (b'), (c') Yaoxianognathus yaoxianensis An, 1985. (y) Lateral view of Pb element, Lijiapo of Longxian, Upper Ordovician Beiguoshan Formation, Leb15-1/65304; (z) Lateral view of Pb element, Taoqupo of Yaoxian, Shaanxi, Upper Ordovician Taoqupo Formation, Tp31y13/84527; (b') Lateral view of $\mathrm{Pb}$ element, Longmendong of Longxian, Shaanxi, Upper Ordovician Longmendong Formation, Lh28-1/65306; ( $\mathrm{c}^{\prime}$ ) Lateral view of S element, Taoqupo of Yaoxian, Shaanxi, Upper Ordovician Taoqupo Formation, Tp31y13. (d'), (e'), (f') Belodina confluens Sweet, 1979. (d') Lateral view of M element, well in Tarim Basin of Xinjiang, Upper Ordovician Lianglitag Formation, Tc1/ 98-2-3-17; (e') Lateral view of S1 element, well in Tarim Basin of Xinjiang, Upper Ordovician Lianglitag Formation, Tz15/98-2-3-15; (f') Lateral view of S1 element, Bachu of Xinjiang, Upper Ordovician Lianglitag Formation, Nj688/122669. Note: The conodont photos are from Wang and Luo [13], An et al. [14], Zhao et al. [20] and Jing et al. [25]. The length of vertical scale $=1 \mathrm{~mm}$, the horizontal scale $=100 \mu \mathrm{m}$.

Katian coincides temporally with the initiation of the Kwangsian Orogeny in southeast China, which may be interpreted as an early Katian regional tectonic event within the scope of the three major blocks of China. Based on the data at hand, we suggest that this emergence event is not caused by a eustatic sea-level lowering but represents a regional tec- tonic uplift in the northeastern peri-Gondwanan regions. For this, the use of the term Kwangsian Orogeny is far more appropriate than the continued use of the term Caledonian Orogeny because the Chinese tectonic event is quite unlikely to have any relationship at all with the latter's mountain-building process in northwestern Europe. 
SMB gratefully acknowledges support from the Nanjing Institute of Geology and Palaeontology that made it possible for him to visit Nanjing in February-March, 2012 when most of this paper was written partly based on a prepared primitive manuscript. This work was supported by the project of the State Key Laboratory of Palaeobiology and Stratigraphy (Y126040124), the National Natural Science Foundation of China (41172034 and 41221001), and the project of the Ministry of Science and Technology of China (2011ZX05008-001-10).

1 Ting V K. The orogenic movements in China (presidential address of the 6th Annual Meeting). Bull Geol Soc China, 1929, 8: 151-170

2 Huang T K. On major tectonic forms of China. Geol Mem Ser A, 1945, 20: 1-165

3 Chen X, Rowley D, Rong J Y, et al. Late Precambrian through Early Paleozoic stratigraphic and tectonic evolution of the Nanling region, Hunan Province, South China. Intl Geol Rev, 1997, 39: 469-478

4 Sadler P M, Cooper R A, Melchin M. High-resolution, early Paleozoic (Ordovician-Silurian) time scales. Geol Soc Amer Bull, 2009, 121: 887-906

5 Chen X, Mitchell C E. Stratigraphic evidences on Taconian and Guangxian Orogeny (in Chinese). J Stratigr, 1996, 20: 305-314

6 Chen X, Zhang Y D, Fan J X, et al. Ordovician graptolite-bearing strata in southern Jiangxi with a special reference to the Kwangsian Orogeny. Sci China Ser D-Earth Sci, 2010, 53: 1602-1610

7 Chen X, Zhang Y D, Fan J X, et al. Onset of the Kwangsian Orogeny as evidenced by biofacies and lithofacies. Sci China Ser D-Earth Sci, 2012, 55: 1592-1600

8 Chen X, Rong J Y, Wang X F, et al. Correlation of the Ordovician rocks of China. IUGS Publ, 1995, 31: 1-104

9 An T X, Zhang F, Xiang W D, et al. The Conodonts of North China and the Adjacent Regions (in Chinese). Beijing: Science Press, 1983. $1-223$

10 Branson E B, Mehl M G. Conodont Studies Number 1. The Univ Missouri Studies, 1933, 8: 1-76

11 Pei F, Cai S H. Ordovician Conodonts from Henan Province (in Chinese). Wuhan: Wuhan College of Geology Publishing House, 1987. $1-128$

12 Zhen Y Y, Burrett C F, Percival I G, et al. A Late Ordovician conodont fauna from the Lower Limestone Member of the Benjamin Limestone in Central Tasmania, and revision of Tasmanognathus careyi Burrett, 1979. Proc Linnean Soc New South Wales, 2010, 131: 43-72

13 Wang Z H, Luo K Q. Late Cambrian and Ordovician conodonts from the marginal areas of the Ordos Platform, China (in Chinese). Bull Nanjing Inst Geol Palaeont Acad Sin, 1984, 8: 237-304

14 An T X, Zhang A T, Xu J M. Ordovician conodonts from Yaoxian and Fuping, Shaanxi and their stratigraphic significance. Acta Geol Sin, 1985, (2): 97-108

15 An T X, Zheng Z C. The Conodonts of the Marginal Areas Around the Ordos Basin (in Chinese). Beijing: Science Press, 1990. 1-201

16 Chen J Y, Zhou Z Y, Zou X P, et al. Outline of Ordovician deposits and faunas in Shandong, N. Anhui and N. Jiangsu, E. China (in Chinese). Mem Nanjing Inst Geol Palaeont Acad Sin, 1980, 16: 159-195
17 Chen J Y, Zhou Z Y, Lin Y K, et al. Ordovician biostratigraphy ofwestern Ordos (in Chinese). Mem Nanjing Inst Geol Palaeont Acad Sin, 1984, 20: 1-31

18 Lin Y K. Research on Middle Ordovician Diplograptid Graptolites from southern border of Ordos Platform (in Chinese). Acta Palaeont Sin, 1996, 35: 389-406

19 Chen X, Ni Y N, Mitchell C E, et al. Graptolites from the Qilang and Yingan formations (Caradoc, Ordovician) of Kalpin, Western Tarim, Xinjiang, China. J Paleont, 2000, 74: 282-300

20 Zhao Z X, Zhang G Z, Xiao J N. Palaeozoic Stratigraphy and Conodonts in Xinjiang (in Chinese). Beijing: Petroleum Industry Press, 2000. 1-340

21 Ni Y N, Chen X. Graptolites from bore cores of northern Tarim Basin, Xinjiang (in Chinese). Acta Palaeont Sin, 1997, 36 (Suppl): 155-167

22 Chen X, Zhang Y D, Li Y, et al. Biostratigraphic correlation of the Ordovician black shales in Tarim Basin and its peripheral regions. Sci China Ser D-Earth Sci, 2012, 55: 1230-1237

23 Wang Z H, Qi Y P. Ordovician conodonts from drillings in the Taklimakan Desert, Xinjiang, NW China. Acta Micropalaeont Sin, 2001, 18: 133-148

24 Zhen Y Y, Wang Z H, Zhang Y D, et al. Middle to Late Ordovician (Darriwilian-Sandbian) conodonts from the Dawangou section, Kalpin area of the Tarim Basin, northwestern China. Rec Austral Mus, 2011, 63: 203-266

25 Jing X C, Du P D, Zhang F, et al. A preliminary study on the Ordovician conodont biostratigraphy at the Yakrik section, northwestern margin of Tarim Basin, Xinjiang (in Chinese). Geol Rev, 2007, 53: 242-249

26 Finney S C, Ethington R L, Repetski J E. The boundary between the Sauk and Tippecanoe Sloss sequences of North America. Acta Palaeont Sin, 2007, 46 (Suppl): 128-134

27 Ross J R P, Ross C A. Ordovician sea-level fluctuations. In: Webby B D, Laurie J R, eds. Global Perspectives on Ordovician Geology. Rotterdam: A. A. Balkema, 1992. 327-335

28 Ross C A, Ross J R P. North American depositional sequences and correlations. In: Cooper J D, Droser M L, Finney S C, eds. Ordovician Odyssey: Short Papers for the 7th International Symposium on the Ordovician System. Pacific section SEPM, 1995, 77: 309-313

29 Nielsen A T. Ordovician sea level changes: A Baltoscandian perspective. In: Webby B D, Paris F, Droser M L, et al. eds., The Great Ordovician Biodiversity Event. New York: Columbia University Press, 2004. 84-93

30 Haq B U, Schutter S R. A Chronology of Paleozoic Sea-Level Changes. Science, 2008, 322: 64-68

31 Dronov A V, Ainsaar L, Kaljo D, et al. Ordovician of Baltoscandia: facies, sequences and sea-level changes. In: Gutiérrez-Marco J C, Rábano I, García-Bellido D, eds. Ordovician of the World. Cuadernos del Museo Geominero, 2011, 14: 143-150

32 Goldman D, Mitchell C E, Melchin M J, et al. Biogeography and mass extinction: Extirpation and re-invasion of Normalograptus species (Graptolithina) in the Late Ordovician Palaeotropics. Proc Yorkshire Geol Soc, 2011, 58: 227-246

33 Goldman D. Taxonomy, evolution and biostratigraphy of the $\mathrm{Or}$ thograptus quadrimucronatus species group (Ordovician, Graptolithina). J Paleont, 1995, 69: 516-540

Open Access This article is distributed under the terms of the Creative Commons Attribution License which permits any use, distribution, and reproduction in any medium, provided the original author(s) and source are credited. 